\title{
Optimization Model of Mariculture in Tuban District
}

\author{
Marita Ika Joesidawati ${ }^{1, *}$, Abdul Wahid Nurrudin ${ }^{2}$, Suwarsih $^{3}$ \\ ${ }^{1,3}$ Study Program Marine Science, Faculty of Fisheries and Marine Science, Universitas PGRI Ronggolawe Tuban \\ ${ }^{2}$ Study Program Industrial Engineering, Faculty of Engenering, Universitas PGRI Ronggolawe Tuban \\ *Corresponding author email: maritajoes@gmail.com
}

\begin{abstract}
Mariculture is one form of an effort to increase fishery production, in addition to capture fisheries. The waters north of Java, Tuban Regency are developing Mariculture using floating net cages with the main commodities of grouper fish. The current problem is the limited supporting industries that meet the needs of seeds, fish feed and mariculture equipment. In addition, the availability of land is limited because it requires quality waters that are clean and free of pollution. Mariculture development requires government policies to encourage the emergence of supporting industries. As a large investment, a supporting industry can only be created if the Mariculture industry is proven to have high economic value. Thus, it is necessary to develop a Mariculture model to identify (1) the size of the industry based on available marine resources (land area and water conditions) and (2) to develop an optimization model with linear programming. The result of this research is a linear programming model and the optimal value of each cultivation commodity. Cultivation commodities consist of grouper.
\end{abstract}

Keywords: linear programing, high economic value, supporting industries.

\section{INTRODUCTION}

The demand for seafood is currently increasing, this condition will not be fulfilled from capture fisheries activities. Based on the latest review regarding the condition of global fishery resources by FAO, it is estimated that of the 523 fish species in the world that were carried out by a stock assessment, $52 \%$ of fish resources were fully exploited, $17 \%$ were overexploited and only $3 \%$ were underexploited [1], so that sea is an alternative to meet the increasing demand for seafood.

Mariculture in Indonesia is still being developed [2] as well as mariculture around the world is also experiencing rapid development [3], but there are still many obstacles and problems in developing mariculture, to anticipate mariculture activities can continue to develop, it is very necessary several studies to reduce or minimize the constraints and problems that will occur, such as a study of water quality and marine pollution levels [4], [5], determining the location of marine culture[6], [7], overcoming seed availability[8], disease management techniques [9], [10]. Mariculture methods with floating net cages (KJA) such as the structure of the floating net cages[11], the strength of the marine cage against the influence of waves and wind [12], [13],[14], determination of stocking density in floating net cages [15] and the impact of floating net cages on the marine environment [16]. Supporting factors for the smooth running of mariculture activities such as mariculture development spatial planning [17], [18], rules of competitive global market competition [19], [20], quality requirements and food safety from countries importer [21].

Mariculture with the floating net cage system in Tuban Regency has begun to be developed, to be precise in 2018 with sepsis cultivants, namely, grouper, grouper, tiger, and humpback grouper placed in the waters of Bancar beach, Tuban coastal waters, the quality of the waters is still good for mariculture activities [6]. The 
catch from capture fisheries in the sea waters of Tuban Regency obtains cultivant species that have the potential to be cultivated with high economic value. These include beronang, grouper, snapper, seaweed and crustaceans [22]. Based on data on the potential of fish resources and water conditions in Tuban Regency, its function is still possible as a mariculture development, even though it has varying characteristics in its hydroooseanographic conditions [23]

The problem is that good cultivation results will be obtained if the density of the species does not exceed the limit, so that the number of fish cultivated depends on the variable land available and the intrinsic characteristics of the species being cultivated. Based on these two things, an estimate can be made of the number of fish seeds, fish feed and equipment for cultivation such as floating net cages and other infrastructure. So this research aims to (1) identify the potential for mariculture development based on land availability, (2) develop an optimization model for mariculture in Tuban waters to determine the products that provide maximum profit.

\section{RESEARCH METHOD}

\subsection{Research Location}

The location of floating net cages in Tuban Regency is located in the coastal waters of Bancar District, precisely in Figure 1

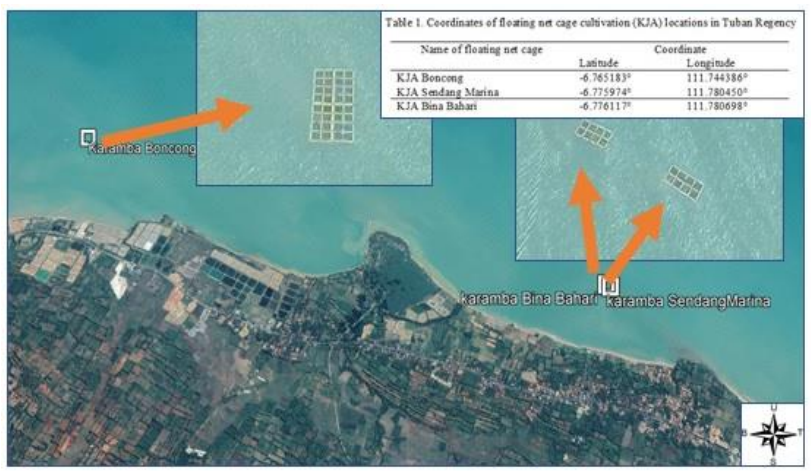

Figure 1. Location of floating net cage (KJA) cultivation in Tuban Regency

The quality of the coastal waters of Tuban Regency is still good for mariculture activities. In June (east season) the productivity of the waters really supports the growth of cultivated biota, while in February (the transitional season) and December (the west season) the productivity of the waters is also good, although not as good as the eastern season. Based on spatial analysis or location area for coastal mariculture activities in Bancar district, it shows the highest value [6].

The production capacity of grouper seedlings from the hatchery is sufficient, because the seeds are produced at IBL Boncong and several hatcheries in Tuban Regency at a price of 1000 per $\mathrm{cm}$ per fish, but it is also less than the potential market for fishery products considering that Tuban is located in the northern part of Java. Rembang, and Lamongan, where there are grouper cultivation in ponds

Cultivation time for tiger grouper (Epinephelus fuscoguttatus), humpback grouper (Chromileptes altivelis) and grouper (Epinephellus fuscoguttatuslanceolatus) with 6 months of KJA. Generally, the grouper harvested from KJA Cultivation is 3-4 fish per $\mathrm{kg}$, with an average selling price of Rp. $75,000 \mathrm{~kg}$, while the grouper cantang Rp. 80,000.

\subsection{Linear Programming}

The mathematical model of general problem formulation of allocating resources to share activities is known as the Linear Programming Model.

The stages in linear programming research or linear programming include (1) problem formulation, (2) linear equation input in the Quant System software, (3) Running software, (4) Sensitivity analysis. Sensitivity analysis is an analysis carried out to determine the effect / effect of changes in LP parameters on the optimal solution that has been achieved. Research on the impact of changes in linear parameter values is known as sensitivity analysis [24].

To develop a linear programming model for mariculture, the model parameters are assumed to be deterministic and constant. Parameters involved in the marine culture fishery model with the floating net cage system with a case study in

1. Assumption of financing capital (IDR / year). The value of capital for land use projects for mariculture is assumed.

2. Types of commodities that are tested are commodities that are physically, chemically, and biologically suitable for cultivation in the case study waters.

3. The area of mariculture land is suitable based on the identification of land suitability (in research is the size of KJA)

4. Hatchery availability, number of seeds used for mariculture

5. Economic parameter, is the value of the coefficient of the following input variables ( $\mathrm{n}$ is the type of commodity):

a. Profit $/ \mathrm{kg}$ of commodity

$c_{n}=\frac{\text { production profit } / y r / h a}{\text { production amount } / y r / h a}$

.... (1)

b. Cost $/ \mathrm{kg}$ of commodity 
$a_{1 n}=\frac{\text { anual invesrment costs }+ \text { operational cost }}{\text { production amount } / y r}$

$$
a_{2 n}=\frac{\text { Landuse } / \mathrm{kg} \text { of commodity }}{\text { production amount } / \mathrm{yr} / \mathrm{ha}}
$$

d. Requirement of seeds from Hatchery $/ \mathrm{kg}$ of comodity

$a_{1 n}=\frac{\text { jthe number of seeds needed } / y r}{\text { production amount } / y r}$

\section{Objective Function: Maximize the $Z$ value}

$$
Z=C_{1} X_{1}+C_{2} X_{2}+C_{3} X_{3}
$$

The constraint functions are as follows:

1) Limited funds

$$
a_{11} X_{1}+a_{12} X_{2}+a_{13} X_{3} \leq b_{1}
$$

2) The maximum potential land capacity for grouper cultivation in $\mathrm{KJA}$

$$
a_{21} X_{1}+a_{22} X_{2}+a_{23} X_{3} \leq b_{2}
$$

3) Availability of seeds

$$
a_{31} X_{1}+a_{32} X_{2}+a_{33} X_{3} \leq b_{3}
$$

$$
\begin{aligned}
& \text { Where } \\
& \mathrm{C} 1=\text { profit } / \mathrm{kg} \text { Humpback grouper } \\
& \mathrm{C} 2=\text { profit } / \mathrm{kg} \text { tiger crabs } \\
& \mathrm{C} 3=\text { profit } / \mathrm{kg} \text { grouper } \\
& \text { a11 = production cost } / \mathrm{kg} \text { Humpback grouper } \\
& \text { a12 = production cost } / \mathrm{kg} \text { tiger grouper } \\
& \text { a13 = production cost } / \mathrm{kg} \text { grouper cantang } \\
& \text { a21 = land requirement } / \mathrm{kg} \text { Humpback grouper } \\
& \text { a22 = land requirement } / \mathrm{kg} \text { tiger grouper } \\
& \text { a23 = land requirement } / \mathrm{kg} \text { grouper cantang } \\
& \text { a31 = seed requirements } / \mathrm{kg} \text { Humpback } \\
& \text { grouper } \\
& \text { a32 = seed requirements } / \mathrm{kg} \text { tiger grouper } \\
& \text { a33 = seed requirement } / \mathrm{kg} \text { grouper cantang } \\
& \text { b1: assumption of total capital or investment } \\
& \text { (IDR) } \\
& \text { b2: land capacity according to the fish in the } \\
& \text { cage } \\
& \text { b3: the number of seeds available }
\end{aligned}
$$

\section{RESULTS AND DISCUSSION}

\subsection{Cultivation of floating net cages (KJA) in Tuban Regency}

KJA cultivation in Tuban Regency with three types of cultivation, more precisely by enlarging groupers with the floating net cage system, is located in the coastal waters of Bancar District, $300 \mathrm{~m}$ from the coastline with a depth of $10-15 \mathrm{~m}$. Analyzed from the determination of the location of cultivation the location of the marine cage is very affordable in terms of feed and marketing access. This is in accordance with the requirements of floating net cages [25], including water depth of at least 7 meters from the lowest tide, the location is protected from waves (not located on the high seas), the wave height is not more than 2 meters, the quality of the waters is not polluted and high fertility productivity. The coastal waters of the Bancar sub-district have plankton diversity compared to other coastal waters in Tuban Regency, which means that the primary productivity in these waters is high [6].

The size of the floating net cage used is $3 \mathrm{~m} \times 3 \mathrm{~m}$ with a depth of 3 meters, with 1 inch and 2 inch meshes which are adjusted to the size of the fish being kept, so that the fish do not come out of the rearing nets, made from PE (polyethylene), and HDPE (aquatec ) $100 \%$ for the foundation of each plot. This is in accordance with [26] statement, that the nets must be made of polyethylene nylon material that is safe for humans, fish and the environment and is durable (Figure 2a)
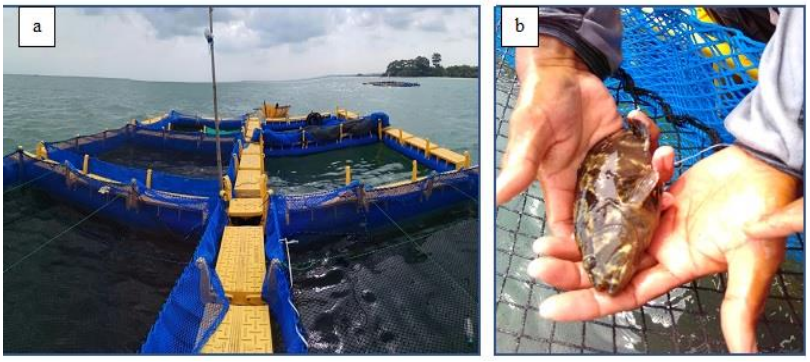

Figure 2. (a) Shape and size of floating net cages (b) Size of Cantang grouper at 2 months of age

Grouper seeds used in the rearing activity in floating net cages are obtained from the Bancar Mutiara Pantai hetchery division, IBL Boncong and if they do not meet production needs, the seeds are taken from Situbondo. The size of the seeds are first stocked measuring $8-12 \mathrm{~cm}$. This is done because at that size the seeds already have perfect limbs, and are able to withstand ocean currents. The maintenance period for grouper to consumption size is 6 months. The standard for selecting seeds is carried out before stocking in the sea, such as: fish seeds are not 
defective, free from disease, have uniform size, have bright colors and have an active response to feed [27].

The factor that needs to be considered in planting seeds is the density of stocking, because it is closely related to the growth and survival of the cultivant. The first fish seeds are stocked in the morning, when the water temperature is not too high, first to acclimatize for 5-10 minutes in a new environment, namely floating net cages. The first stocking density for silver measuring $3 \times 3 \times 3$ $\mathrm{m}$ is 900 individuals [28]. When the seeds are $15 \mathrm{~cm}$ in size, they are transferred with a maximum stocking density of 500 individuals in cages of the same size $(3 \times 3 \times 3 \mathrm{~m})$. After 1 week, grading activities are carried out for the purpose of grouping fish and reducing cannibalism. The next grading is done every month until harvest (6 months).

The feed given is trash fish obtained from trash fish collectors in the Bancar area for Rp. 3,500/kg. The main feed in the form of trash fish is adjusted to the mouth size of the grouper, and is given once a day, where the average requirement for each plot consumes $5 \mathrm{~kg}$ of trash fish. Feeding trash fish is carried out in the morning at 06.00 WIB, on the grounds that in the morning the water temperature is still stable and not too high, because the fish are sensitive to environmental changes, one of which is temperature. If the water temperature is at a level that is not optimal, it will reduce the appetite for fish so that it can interfere with fish growth [29]. The method of giving is the Ad satiation method, namely by spreading the feed little by little continuously according to the appetite of the fish. This is done so that there is no accumulation of leftover feed at the bottom of the cage. Because grouper fish tend to like food that is on the surface, usually when it is at the bottom of the cage the food is left alone and is not eaten by groupers.

Observation of water quality is also carried out by monitoring, including temperature, $\mathrm{pH}$ and $\mathrm{DO}$, which is carried out once a week, during the rearing activity (6 months) where the average $\mathrm{pH}$ of the waters is $8.1-8.4$, temperature is $28-30 \mathrm{oC}$, and DO $5.4-6.44 \mathrm{mg} / \mathrm{l}$, all of which are still eligible for mariculture activities[6].

\subsection{Linear Programming Formulation}

The values of the parameters that have been identified based on the linear programming model for mariculture with the KJA system in the coastal waters of Tuban Regency are as follows:

1. The area of land in the KJA is 0.027 hectares, (the area of the compartments of the active KJA for enlargement activities is 30 plots of the 48 existing plots

2. Financing capital of IDR $1,549,000,000$ with the type of cultivant, namely grouper fish (duck, tiger, and cantang)

3. Availability of seeds in the hatchery 54000 heads.
4. Economic parameters are calculated from the analysis of the cost of each commodity based on the cost of mariculture.

Linear programming model parameters are entered into a mathematical formulation.

Objective Function: Maximize the $\mathrm{Z}$ value $\mathrm{Z}=149710 \mathrm{X}_{1}+155187 \mathrm{X}_{2}+188276 \mathrm{X}_{3}$

The constraint functions are as follows:

1) Limited funds

$$
\begin{gathered}
332454 X_{1}+336898 X_{2}+349885 X_{3} \leq \\
1549000000
\end{gathered}
$$

2) The maximum potential land capacity for grouper cultivation in KJA

$$
1,781.10^{-8} \mathrm{X} 1+1,805.10^{-8} \mathrm{X}_{2}+7,448.10^{-8} \mathrm{X}_{3}
$$

$\leq 0,027$

3) Availability of seeds

$$
0,036 \mathrm{X}_{1}+0,036_{2} \mathrm{X}_{2}+0.149 \mathrm{X}_{3} \leq 54000
$$

\subsection{Analysis of Optimization Results}

The problem of mariculture optimization model using linear programming is then solved with the help of QS software. Based on the QS output, the marine culture optimization model achieves the optimal solution with a value of Rp. 2,278,000,000. This value is achieved by the decision variables produced, namely $\mathrm{X} 1=2500 \mathrm{~kg}, \mathrm{X} 2=$ $2375 \mathrm{~kg}$ and $\mathrm{X} 3=9200 \mathrm{~kg}$

These results illustrate that from an economic perspective, the average production activity generates the same profit. If it is seen from the amount of production, it is cantang grouper, because the cultivation activity is carried out in 20 plots, while grouper and duck grouper are 5 plots each, which produces maximum profit is kerapu production

When viewed from the relative profit value of seaweed farming using return cost ratio $(\mathrm{R} / \mathrm{C})$ analysis, cantang grouper obtained the greatest value compared to other commodities, namely 1.64, while grouper humpback grouper was 1.43 and grouper variety 1.40 with survival rates. the highest number of humpback grouper $(75.8 \%)$, tiger grouper $(74.6 \%)$ and the lowest grouper cantang $(72.5 \%)$

\subsection{Changes to the right side of a constraint}

The results of the sensitivity analysis of the B value (right hand side) of the QS software for each limiting function: 
1. Investment capital: it is known that the current base solution will remain optimal if the price of the right side of the first bounding is between IDR 256,500,000 to $1,036,000,000$. This means that the investment capital value above IDR 2,278,000,000 and below IDR 10,154,000,000 will not change the current optimal solution.

2. The value of the right side of the second delimiter is between 0.0288 and infinity. This means that if the land area suitable for mariculture in KJA is reduced to below 0.0288 ha, then this can change this optimal solution.

3. The price of the right side of the third barrier is between 0 and 86400 . This means that if the hatchery availability increases to above 86400 birds then this will change the current optimum solution.

The model developed in this study does not involve a limit on the demand for each commodity. This is because it is still very difficult to capture the demand for each commodity. The approach taken is to compare the potential for production with the potential for consumption in the region. Mariculture in Tuban Regency only started in 2018. Likewise, grouper hatchery businesses only exist because of the need for grouper fish cultivation in the floating net cage system. This situation is to meet the needs of groupers which have high economic value. Based on the trial, if the value of the availability of seeds is reduced and you have to take them from another city, the total profit is reduced by $20 \%$. This indicates that the limitations of the hatchery affect the decisions as well as potential benefits. For this reason, hatcheries need to be developed so that fishery production results are more stable. Further research is needed on production efficiency so as to increase the profit margin of commodities. Mariculture development requires proper planning and management so that the business system can be carried out in a sustainable manner. The success of sustainable cultivation can be seen, among others, in terms of economic efficiency, social equility, and ecological sustainability. In developing this mariculture linear optimization model, the focus will be on the aspect of economic efficiency without paying attention to the value chain at the next level.

\section{CONCLUSION}

The potential for mariculture development based on the availability of land in Tuban Regency still really needs to be developed, this can be seen in the area of coastal waters at a distance of $300 \mathrm{~m}$ from the coastline which is still untapped and only utilized by the floating net cage system with an area of 0.0432 ha but with the area of the active plot used was only 0.027 ha

The mariculture linear optimization model with the linear programming approach developed is a model with the objective of maximizing profits and with limitations in the form of availability of funds, limited cultivation land (floating net cage area), and hatchery limitations. With three types of grouper cultivar commodity, namely tiger grouper (Epinephelus fuscoguttatus), humpback grouper (Chromileptes altivelis) and grouper (Epinephellus fuscoguttatus-lanceolatus). The optimal solution with a value of IDR 2,278,000,000. This value is achieved by the decision variables produced, namely humpback grouper $=2500 \mathrm{~kg}$, tiger grouper $=2375 \mathrm{~kg}$ and cantang grouper $=9200 \mathrm{~kg}$, with a record of survival rate for humpback grouper (75.8\%), tiger grouper $(74.6 \%)$ and cantang grouper. $(72.5 \%)$

\section{ACKNOWLEDGMENT}

Thank you to the owners of the floating marine cage IBL Boncong, KJA Sendang Marina, and KJA Bina Bahari and Hatcery IBL Boncong and Bancar Mutiara Pantai in Bancar District, Tuban Regency who helped obtain the data for this research.

\section{REFERENCES}

[1] F. FAO, "Aquaculture Department Food and Agriculture Organization of the United Nations, The state of world fisheries and aquaculture 2008." Electronic Publishing Policy and Support Branch Communication Division FAO, Rome, 2009.

[2] J. Hutabarat, "Studi Penyusunan dan Pemetaan Potensi Budidaya Laut di Perairan Kabupaten Rembang Propinsi Jawa Tengah," ILMU Kelaut. Indones. J. Mar. Sci., vol. 10, no. 4, pp. 237244, 2005.

[3] FAO, Adaptation Strategies of the Aquaculture Sector To the Impacts of Climate Change, vol. 2. 2017.

[4] M. I. Joesidawati, S. Suwarsih, and A. Tribina, "ANALISA KUALITAS AIR DAN KOMPOSISI FITOPLANKTON PADA TAMBAK BUDIDAYA UDANG VANNAMEI DI KABUPATEN TUBAN," Pros. SNasPPM, vol. 4, no. 1 SE-Articles, Sep. 2019, [Online]. Available: http://prosiding.unirow.ac.id/index.php/SNasPP M/article/view/263.

[5] S. S.S. et al., "Effect of Mariculture on biooptical properties and water quality of Gulf of Mannar and Palk Bay," Reg. Stud. Mar. Sci., vol. 29, p. 100618, 2019, doi: https://doi.org/10.1016/j.rsma.2019.100618.

[6] M. I. Joesidawati, "KAJIAN KUALITAS AIR SEBAGAI DASAR PEMETAAN LOKASI BUDIDAYA LAUT DI PERAIRAN KABUPATEN TUBAN-JAWA TIMUR," Techno-Fish, vol. 2, no. 2, pp. 59-70, 2018. 
[7] I. N. Radiarta, A. Saputra, and O. Johan, "PEMETAAN KELAYAKAN LAHAN UNTUK PENGEMBANGAN USAHA BUDI DAYA LAUT DENGAN APLIKASI INDERAJA DAN SISTEM INFORMASI GEOGRAFIS DI PERAIRAN LEMITO. PROVINSI GORONTALO," J. Penelit. Perikan. Indones., vol. 11, no. 1, pp. 1-14, 2017.

[8] L. Adam, "Kebijakan Pengembangan Perikanan Berkelanjutan (Studi Kasus: Kabupaten Wakatobi, Provinsi Sulawesi Tenggara dan Kabupaten Pulau Morotai, Provinsi Maluku Utara)," J. Perikan. dan Kelaut., vol. 2, no. 2, pp. 115-126, 2012.

[9] D. C. Huston, K. Ogawa, S. Shirakashi, and B. F. Nowak, "Metazoan Parasite Life Cycles: Significance for Fish Mariculture," Trends Parasitol., vol. 36, no. 12, pp. 1002-1012, 2020, doi: https://doi.org/10.1016/j.pt.2020.07.011.

[10] A. R. Brown et al., "Stakeholder perspectives on the importance of water quality and other constraints for sustainable mariculture," Environ. Sci. Policy, vol. 114, pp. 506-518, 2020 , doi: https://doi.org/10.1016/j.envsci.2020.09.018.

[11] Y. Wei, Q. Wei, and D. An, "Intelligent monitoring and control technologies of open sea cage culture: A review," Comput. Electron. Agric., vol. 169, p. 105119, 2020, doi: https://doi.org/10.1016/j.compag.2019.105119.

[12] H. Qin, S. Yu, and P. Li, "Dynamic response of floating collar and cage under waves and current," Ocean Eng., vol. 205, p. 107330, 2020, doi:

https://doi.org/10.1016/j.oceaneng.2020.10733 0.

[13] Y. C. Guo, S. C. Mohapatra, and C. Guedes Soares, "Review of developments in porous membranes and net-type structures for breakwaters and fish cages," Ocean Eng., vol. 200, p. 107027, 2020, doi: https://doi.org/10.1016/j.oceaneng.2020.10702 7.

[14]X. Bai, Y. Zhao, G. Dong, and C. Bi, "Probabilistic analysis and fatigue life assessment of floating collar of fish cage due to random wave loads," Appl. Ocean Res., vol. 81, pp. 93-105, 2018, doi: https://doi.org/10.1016/j.apor.2018.09.018.

[15] L. Li, S. Fu, Y. Xu, J. Wang, and J. Yang, "Dynamic responses of floating fish cage in waves and current," Ocean Eng., vol. 72, pp. 297-303, 2013, doi: https://doi.org/10.1016/j.oceaneng.2013.07.004

[16] A. Sabdono, O. K. Radjasa, A. Trianto, Sarjito,
Munasik, and D. P. Wijayanti, "Preliminary study of the effect of nutrient enrichment, released by marine floating cages, on the coral disease outbreak in Karimunjawa, Indonesia," Reg. Stud. Mar. Sci., vol. 30, p. 100704, 2019, doi: https://doi.org/10.1016/j.rsma.2019.100704.

[17]R. K. Craig, "Fostering adaptive marine aquaculture through procedural innovation in marine spatial planning," Mar. Policy, vol. 110, p. $103555, \quad 2019, \quad$ doi: https://doi.org/10.1016/j.marpol.2019.103555.

[18] A. Gimpel et al., "A GIS modelling framework to evaluate marine spatial planning scenarios: Co-location of offshore wind farms and aquaculture in the German EEZ," Mar. Policy, vol. 55, pp. 102-115, 2015, doi: https://doi.org/10.1016/j.marpol.2015.01.012.

[19] H. T. Putra and E. A. Aqimuddin, "Pengaturan Subsidi Perikanan dalam WTO dan Dampaknya Bagi Indonesia," Mimb. Hukum-Fakultas Huk. Univ. Gadjah Mada, vol. 26, no. 3, pp. 395-408, 2014.

[20] R. I. Khaldun, "Strategi Kebijakan Peningkatan Daya Saing Rumput Laut Indonesia di Pasar Global," J. Sos. Polit., vol. 3, no. 1, pp. 99-125, 2017.

[21] J. Yu and Q. Han, "Food security of mariculture in China: Evolution, future potential and policy," Mar. Policy, vol. 115, p. 103892, 2020, doi: https://doi.org/10.1016/j.marpol.2020.103892.

[22]F. KurniawanAditama, "Peranan Tempat Pelelangan Ikan (Tpi) Dalam Pemasaran Ikan Hasil Tangkapan Nelayan Di Tempat Pelelangan Ikan (Tpi) Bulu Desa Bulumeduro Kecamatan Bancar Kabupaten Tuban, Jawa Timur." Universitas Brawijaya, 2016.

[23] M. Aflah, M. I. Joesidawati, and R. N. Sukma, "STUDI TENTANG KUALITAS PERAIRAN PANTAI DAN SUMUR BOR TERHADAP KUALITAS PERAIRAN TAMBAK UDANG VANNAMEI (Litopenaeus vannamei)," Pros. SNasPPM, vol. 2, no. 1 SE-Articles, Sep. 2017, [Online]. Available: http://prosiding.unirow.ac.id/index.php/SNasPP M/article/view/110.

[24] R. Purwaningsih, Z. Fanani Rosyada, and V. SHANY NUGRAHAENI, "MODEL OPTIMASI PERIKANAN BUDIDAYA LAUT (Studi Kasus Perairan Karimunjawa, Kabupaten Jepara)," 2014.

[25]BSN, "SNI 01-7222-2006: Karamba Jaring Apung (KJA) Kayu untuk Pembesaran Ikan Kerapu di Laut," p. 7, 2006.

[26] W. Soemarjati, A. B. Muslim, R. Susiana, and 
C. Saparinto, Bisnis dan budi daya kerapu. Penebar Swadaya Grup, 2015.

[27] K. K. P. D. P. Budidaya, "Profil Ikan Kerapu Indonesia," Direktorat Produksi. Jakarta, vol. 133, 2011.

[28] W. W. F. Indonesia, "Budidaya Ikan Kerapu Macan Sistem Karamba Jaring Apung.” Jakarta, 2015.

[29] K. Sugama, S. Ismi, K. M. Setiawati, M. Rimmer, S. McBride, and K. Williams, "Effect of water temperature on growth, survival and feeding rate of humpback grouper (Cromileptes altivelis) larvae," ACIAR Monogr. Ser., vol. 110, pp. 61-66, 2004. 